\title{
Pengembangan Media Pembelajaran Matematika Berbasis Visual Basic Untuk Siswa Kelas VIII SMP
}

\author{
Nurdin Arsyad ${ }^{1, \text { a) }}$, Nasrullah ${ }^{1, \text { b) }}$, dan Adinda Rezeky Anggriani ${ }^{1, c)}$ \\ ${ }^{1}$ Jurusan Matematika, Fakultas MIPA, Universitas Negeri Makassar \\ a) nurdin.arsyad@unm.ac.id \\ b)nasrullah@unm.ac.id \\ c) adindarezekya@gmail.com
}

\begin{abstract}
Abstrak. Penelitian pengembangan ini bertujuan untuk mengembangkan media pembelajaran matematika berbasis visual basic dan mendeskripsikan kualitas media berdasarkan aspek kevalidan, kepraktisan, dan keefektifan. Penelitian ini adalah penelitian pengembangan dengan model ADDIE yang meliputi 5 tahapan yaitu analysis, design, development, implementation, dan evaluation. Instrumen penelitian berupa lembar penilaian media oleh pakar materi, pakar media dan guru untuk mengukur kevalidan; angket respons terhadap media dan lembar observasi keterlaksanaan pembelajaran untuk mengukur kepraktisan; serta tes hasil belajar untuk mengukur keefektifan media. Responden uji coba produk adalah siswa kelas VIII SMP dengan jumlah siswa 6 orang. Hasil penelitian menunjukkan bahwa penilaian oleh pakar materi, pakar media, dan guru diperoleh kriteria sangat baik sehingga media yang dikembangkan dinyatakan valid. Hasil analisis data angket respons guru dan respons siswa terhadap media dikategorikan sangat baik. Hasil observasi keterlaksanaan pembelajaran juga menunjukkan klasifikasi sangat baik sehingga media dinyatakan praktis. Persentase ketuntasan klasikal dari tes hasil belajar siswa mencapai 83,3\% sehing ga media dinyatakan efektif.
\end{abstract}

Kata Kunci: pengembangan, media pembelajaran matematika berbasis visual basic, ADDIE.

\begin{abstract}
The purposes of this research are to develop mathematical learning media based on visual basics and describe the quality of the media based on aspects of validity, practicality, and effectiveness. This type of research is development research with the ADDIE model which includes 5 stages: analysis, design, development, implementation, and evaluation. The instruments used in this research are the form of media assessment sheets by material experts, media experts, and teachers to measure validity; response questionnaires for the media and observation sheets for the learning implementation to measure practicality; and learning outcomes tests to measure the effectiveness of the media. Respondents for the product trial are students of class VIII SMP which consists of 6 students. The results showed that the assessment by material experts, media experts, and teacher obtained very good criteria so that the media was declared valid. The results of the response questionnaire analysis of teacher and students to the media obtained very good criteria. The results of observations of the implementation of learning showed a very good classification. The percentage of classical completeness from student learning outcomes tests reached $83,3 \%$ so the media was declared effective.
\end{abstract}

Keywords: development, mathematical learning media based on visual basic, ADDIE.

\section{PENDAHULUAN}

Matematika menjadi salah satu bagian yang memegang peranan penting dalam dunia pendidikan. Sebagai bukti, mata pelajaran matematika merupakan mata pelajaran yang diajarkan pada tingkat SD, SMP, SMA hingga perguruan tinggi. Matematika adalah ilmu tentang logika, mengenai bentuk, susunan, besaran, dan konsep-konsep yang berhubungan satu dengan yang lainnya (James \& James, 1976). Dalam aktivitas pembelajaran, setiap materi mata pelajaran 
matematika memiliki tingkat kesukaran yang beragam. Matematika memiliki karakteristik yakni objek pembicaraannya yang abstrak.

Salah satu materi matematika yang memiliki sifat abstrak adalah geometri khususnya pada materi bangun ruang. Bangun-bangun geometri yang sifatnya abstrak merupakan benda-benda pikiran yang memiliki bentuk dan ukuran serba sempurna (Abdussakir, 2009). Pokok bahasan di dalam geometri yang diajarkan pada siswa kelas VIII adalah bangun ruang. Geometri ruang merupakan himpunan semua titik, garis, dan bidang dalam ruang berdimensi tiga yang terletak dalam bagian tertutup beserta seluruh permukaan yang membatasinya (Suwaji, 2008). Adapun jenis-jenis geometri ruang misalnya kubus, balok, prisma, limas, dan sebagainya. Di antara berbagai cabang matematika, geometri menempati posisi yang paling memprihatinkan (Sudarman, 2000).

Kesulitan dalam belajar geometri menyebabkan pemahaman yang kurang sempurna terhadap konsep-konsep geometri yang pada akhirnya menghambat proses belajar geometri selanjutnya. Madja (1992) mengemukakan bahwa hasil tes geometri siswa kurang memuaskan jika dibandingkan dengan materi matematika yang lain terutama pada konsep bangun ruang. Kelemahan siswa terhadap materi bangun ruang juga dapat dilihat pada hasil PISA 2012 yang menunjukkan bahwa siswa lemah dalam geometri, khususnya dalam pemahaman ruang dan bentuk (Muslimin \& Sunardi, 2019). Oleh karena itu, diperlukan suatu pembaharuan dari guru sebagai fasilitator dalam proses pembelajaran di kelas.

Dengan memanfaatkan sarana dan prasarana pembelajaran seperti penggunaan media pembelajaran dapat membantu guru untuk menciptakan suasana pembelajaran menjadi lebih menarik. Media pembelajaran adalah segala sesuatu yang digunakan untuk menyalurkan pesan dari pengirim ke penerima sehingga merangsang pikiran, perasaan, perhatian, dan minat serta kemauan siswa sedemikian rupa sehingga proses ajar terjadi dalam rangka mencapai tujuan pembelajaran secara efektif (Prayoga, 2018). Kehadiran media dalam pembelajaran bukan hal yang utama. Meskipun demikian, penggunaan media dalam pembelajaran dapat memberikan kontribusi besar dalam upaya mencapai tujuan pembelajaran. Media pembelajaran matematika dapat dikembangkan dengan menggunakan program aplikasi visual basic 6.0.

Visual basic adalah salah satu bahasa pemrograman komputer (Kusrini \& Koniyo, 2007). Visual basic merupakan bahasa pemrograman yang sangat mudah dipelajari, dengan teknik pemrograman visual yang memungkinkan penggunanya untuk berkreasi lebih baik dalam menghasilkan suatu program aplikasi. Dengan adanya microsoft visual basic 6.0 ini dapat memudahkan para programmer untuk membuat program yang familiar untuk pemakai (User) karena menggunakan visualisasi dan animasi serta tampilan yang menarik untuk dilihat. Sehingga, diharapkan penggunaan komputer dalam media pembelajaran berbasis visual basic dapat mempermudah siswa untuk memahami dan menguasai materi yang bersifat abstrak khususnya bangun ruang sisi datar.

Terdapat beberapa penelitian yang telah dilakukan terkait dengan pengembangan media pembelajaran visual basic. Rosmayanti dan Zanthy (2019) mengembangkan media pembelajaran berbasis visual basic application powerpoint yang valid dan digunakan dalam proses pembelajaran pada materi SPLDV. Rohaeti, Bernard dan Novtiar (2019) mengembangkan media visual basic application pada materi peluang menunjukkan bahwa media layak digunakan dalam pembelajaran di kelas.

Selain itu, penelitian yang dilakukan oleh Kuswanto (2017) tentang pengembangan game berhitung dengan menggunakan visual basic 6.0 pada mata pelajaran matematika. Hasil penelitiannya menunjukkan bahwa produk game berhitung dinyatakan baik berdasarkan penilaian oleh para ahli. Sementara responden memberikan respons yang sangat baik sebab 
dengan adanya aplikasi permainan berhitung, proses pembelajaran menjadi tidak membosankan dan siswa dapat belajar sambil bermain.

Penelitian ini berfokus pada pengembangan media pembelajaran matematika berbasis visual basic untuk siswa SMP pada materi bangun ruang sisi datar terkhusus kubus dan balok. Penelitian ini bertujuan untuk mengembangkan dan mendeskripsikan kualitas media pembelajaran ditinjau dari aspek kevalidan, kepraktisan, dan keefektifan.

\section{METODE PENELITIAN}

Penelitian ini merupakan pengembangan dengan menggunakan model Analysis, Design, Development, Implementation dan Evaluation (ADDIE). Responden uji coba produk pengembangan adalah siswa kelas 8 di salah satu sekolah di Kepulauan Selayar dengan jumlah siswa 6 orang. Penelitian ini dilaksanakan saat masa pandemi covid-19 sehingga responden uji coba dipilih berdasarkan jarak tempuh rumah terdekat dari lokasi penelitian.

Teknik pengumpulan data yang digunakan untuk mengembangkan media visual basic yaitu lembar validasi, observasi, kuesioner (angket), dan tes. Instrumen penelitian yang digunakan berupa (1) lembar penilaian media oleh ahli media, ahli materi, dan guru untuk mengukur kevalidan, (2) lembar observasi keterlaksanaan pembelajaran, angket respons guru dan respons siswa untuk mengukur kepraktisan media visual basic, dan (3) tes hasil belajar untuk mengukur keefektifan. Serta terdapat pula perangkat pembelajaran berupa Rencana Pelaksanaan Pembelajaran (RPP) dan Lembar Kerja Peserta Didik (LKPD).

\section{Analisis Data Kevalidan Media Pembelajaran Matematika}

Lembar penilaian yang digunakan berfungsi sebagai alat untuk mengukur kualitas kevalidan berupa kelengkapan dari isi, tujuan, format penulisan, bahasa, instruksional dan aspek teknis. Data hasil penilaian ahli media, ahli materi dan guru matematika dianalisis menggunakan persamaan 1.

Keterangan:

$$
\bar{x}=\frac{\sum_{i=1}^{n} x_{i}}{n}
$$

$\bar{x} \quad=$ rata-rata skor yang diperoleh

$\sum_{i=1}^{n} x_{i}=$ jumlah skor yang diperoleh ke- $i$

$n \quad=$ banyaknya butir pertanyaan

Mengkonversikan skor rata-rata menjadi data kualitatif skala lima yang merujuk pada Tabel 1.

TABEL 1. Kriteria Kevalidan dan Kepraktisan Media Pembelajaran

\begin{tabular}{cl}
\hline Interval & \multicolumn{1}{c}{ Kriteria } \\
\hline$x>4,2$ & Sangat Baik \\
$3,4<x \leq 4,2$ & Baik \\
$2,6<x \leq 3,4$ & Cukup Baik \\
$1,8<x \leq 2,6$ & Kurang Baik \\
$x \leq 1,8$ & Sangat Kurang \\
\hline & Widoyoko (2009)
\end{tabular}

Produk penelitian berupa media pembelajaran matematika yang dikembangkan memenuhi kualifikasi valid apabila skor rata-rata penilaian ahli media, ahli materi dan guru matematika terhadap media yang dikembangkan mencapai kriteria minimal baik. 


\section{Analisis Data Kepraktisan Media Pembelajaran Matematika}

Instrumen angket respons guru dan siswa terhadap media bertujuan untuk mengetahui kualitas kepraktisan berdasarkan tanggapan guru dan siswa terhadap manfaat dan kemudahan penggunaan media. Cara penilaian dilakukan dengan menghitung skor rata-rata menggunakan persamaan (1). Selanjutnya, skor rata-rata tersebut dikonversi menjadi data kualitatif skala lima merujuk pada Widoyoko (2009), seperti yang disajikan pada Tabel 1.

Kriteria penilaian keterlaksanaan pembelajaran disajikan pada Tabel 2.

TABEL 2. Kriteria Penilaian Keterlaksanaan Kegiatan Pembelajaran

\begin{tabular}{cc}
\hline Rentang Persentase & Kriteria \\
\hline$p \geq 90 \%$ & Sangat Baik \\
$80 \% \leq p<90 \%$ & Baik \\
$70 \% \leq p<80 \%$ & Cukup Baik \\
$p<60 \%$ & Kurang Baik \\
\hline & Sudjana (2013)
\end{tabular}

Media pembelajaran yang dikembangkan memenuhi klasifikasi praktis apabila media memberi kemudahan kepada pengguna dan skor rata-rata angket respons guru dan siswa terhadap media memenuhi kriteria minimal baik serta persentase rata-rata keterlaksanaan kegiatan pembelajaran memenuhi kriteria minimal baik.

\section{Analisis Data Keefektifan Media Pembelajaran Matematika}

Analisis keefektifan dilakukan menggunakan tes hasil belajar. Analisis dilakukan dengan menghitung nilai rata-rata siswa, lalu menghitung jumlah siswa yang lulus KKM yaitu siswa yang mendapatkan nilai lebih dari atau sama dengan 75 berdasarkan KKM sekolah. Setelah itu, menghitung persentase ketuntasan klasikal dengan menggunakan rumus 2.

Keterangan:

$$
p=\frac{L}{n} \times 100 \%
$$

$$
\begin{array}{ll}
p & =\text { persentase kelulusan siswa secara klasikal } \\
L & =\text { banyaknya siswa yang lulus KKM } \\
n & =\text { banyaknya siswa }
\end{array}
$$

Kemudian data dikonversi menjadi data kualitatif dengan menggunakan kriteria penilaian yang disajikan pada Tabel 3.

TABEL 3. Kriteria Keefektifan Media Pembelajaran

\begin{tabular}{cc}
\hline Interval & Kriteria \\
\hline $80 \%<p$ & Sangat baik \\
$60 \%<p \leq 80 \%$ & Baik \\
$40 \%<p \leq 60$ & Cukup baik \\
$20 \%<p \leq 40 \%$ & Kurang baik \\
$p \leq 20$ & Tidak Baik \\
\hline & Widoyoko (2009)
\end{tabular}

Kualitas media dikatakan efektif jika para pakar dan pengguna menyatakan bahwa media tersebut efektif dan memberikan hasil yang sesuai dengan harapan. 


\section{HASIL DAN PEMBAHASAN}

Penelitian dan pengembangan yang dilakukan ini menghasilkan media pembelajaran matematika yang telah divalidasi dan diujicobakan ke guru dan siswa. Penelitian ini menggunakan model pengembangan ADDIE, yang meliputi lima tahapan yaitu Analysis (Analisis), Design (Desain/Rancangan), Development (Pengembangan), Implementation (Implementasi), dan Evaluation (Evaluasi).

\section{Analisis}

\section{Analisis Karakteristik Siswa}

Analisis karakteristik siswa dapat diperoleh dari teori yang relevan, hasil observasi atau pengamatan saat pembelajaran berlangsung, dan wawancara terhadap guru matematika. Kajian teori perkembangan kognitif Jean Piaget (Faizah, Rahma, \& Dara, 2017) mengatakan bahwa pada umumnya siswa SMP kelas VIII berada pada tahap keempat yaitu operasional formal.

Melalui observasi atau pengamatan ketika pembelajaran, menunjukkan bahwa siswa SMP kelas VIII sudah mampu memecahkan masalah dengan baik khususnya dalam konteks sehari-hari. Namun, siswa tetap memerlukan bantuan dari guru dan bantuan media dalam kegiatan pembelajaran matematika agar siswa dapat memahami materi yang dipelajari dengan baik. Siswa lebih mudah memahami materi yang bersifat nyata dan konkret terutama dalam konteks kehidupan sehari-hari. Kemampuan siswa dalam hal mengoperasikan komputer juga sudah cukup baik seperti menghidupkan komputer, membuka aplikasi, mengetik, dan mematikan komputer seiring dengan perkembangan teknologi saat ini.

\section{Analisis Situasi}

Pembelajaran tatap muka pada tiap sekolah di Kabupaten Kepulauan Selayar selama pandemi belum diizinkan untuk dilaksanakan dan masih dilakukan secara daring (dalam jaringan). Sesuai izin dari kepala sekolah, sehingga penelitian dilaksanakan di rumah dengan syarat tetap mengikuti protokol kesehatan dan jumlah siswa tidak lebih dari 6 orang. Adapun laptop yang digunakan dalam penelitian ini disediakan dengan rincian satu laptop dapat digunakan oleh 2 orang siswa.

\section{Analisis Kurikulum}

Sesuai dari hasil observasi terhadap pelaksanaan pembelajaran matematika di kelas, diperoleh bahwa kurikulum yang digunakan yaitu kurikulum 2013 (K13). Penyesuaian isi materi dalam media pembelajaran disesuaikan dengan buku Matematika dan mengarahkan siswa aktif dalam pembelajaran.

\section{Perancangan}

Pada tahap ini ada beberapa fase perencanaan diantaranya yaitu menyusun flowchart, menyusun instrumen penelitian, menyusun materi dan latihan soal, membuat Rencana Pelaksanaan Pembelajaran (RPP) beserta Lembar Kegiatan Peserta Didik (LKPD).

\section{Menyusun Flowchart}

Flowchart merupakan suatu bagan dengan simbol-simbol tertentu yang menggambarkan urutan proses secara mendetail dan hubungan antara suatu proses (instruksi) dengan proses lainnya dalam suatu program. 


\section{Menyusun Instrumen Penelitian}

Instrumen penelitian disusun sebagai alat untuk memperoleh data penelitian. Lembar penilaian media oleh pakar materi, pakar media dan guru untuk mengukur kualitas kevalidan media. Angket respons guru terhadap media, angket respons siswa terhadap media, dan lembar observasi keterlaksanaan pembelajaran untuk mengetahui kualitas kepraktisan media. Serta tes hasil belajar siswa digunakan untuk mengukur keefektifan media pembelajaran.

\section{Menyusun Materi dan Latihan Soal}

Naskah materi terdiri dari materi bangun ruang sisi datar terkhusus kubus dan balok. Untuk melatih kemampuan siswa dalam memahami materi pada media, maka juga disusun soal-soal yang dimasukkan ke dalam media yang dikembangkan. Latihan soal diberikan untuk mengukur sejauh mana pemahaman siswa tentang materi dalam media visual basic.

\section{Membuat RPP dan LKPD}

Perangkat Pembelajaran meliputi alokasi waktu, standar kompetensi, kompetensi dasar, indikator, tujuan pembelajaran, uraian materi, langkah-langkah kegiatan pembelajaran, alat, media dan sumber pembelajaran yang digunakan. Perangkat pembelajaran terdiri dari Rencana Pelaksanaan Pembelajaran (RPP) dilengkapi dengan Lembar Kegiatan Peserta Didik (LKPD) sebagai wadah melatih pemahaman siswa dari materi yang diperoleh.

\section{Pengembangan}

Pada tahap ini akan dijelaskan mengenai pembuatan media pembelajaran visual basic, validasi perangkat pembelajaran, serta revisi media pembelajaran.

\section{Pembuatan Media Pembelajaran Visual Basic}

Media pembelajaran yang dikembangkan memuat berbagai kegiatan yang dikelompokan dalam 5 pilihan menu utama, yaitu petunjuk, kompetensi, materi, latihan, dan profil. Berikut merupakan tampilan dari hasil pengembangan media pembelajaran matematika berbasis visual basic yang disajikan dalam Gambar 1.

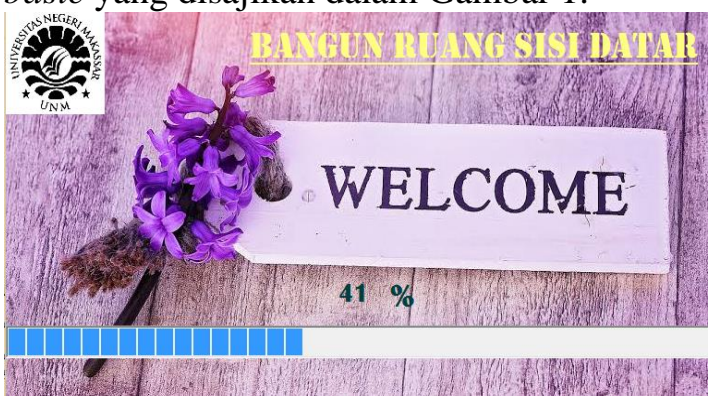

(a)

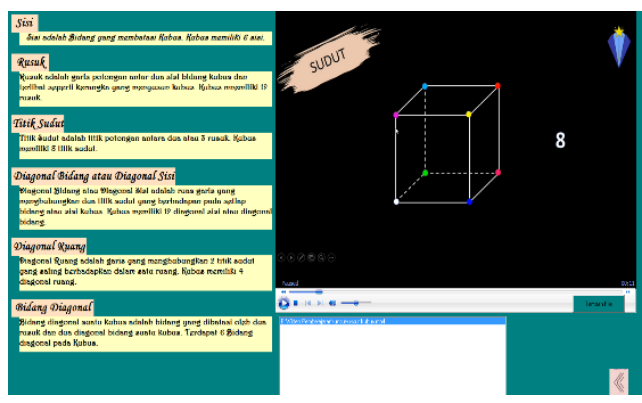

(b)

GAMBAR 1. Tampilan Media Pembelajaran Matematika Visual Basic

\section{Validasi Media Pembelajaran}

Sebelum divalidasi oleh dosen ahli, terlebih dahulu produk media pembelajaran dikonsultasikan kepada dosen pembimbing. Dari hasil konsultasi diperoleh beberapa masukan mengenai media pembelajaran visual basic yaitu penyesuaian warna dari berbagai tampilan perlu diserasikan dan materi yang terdapat pada satu tampilan perlu diringkas kembali. 
Penilaian media bertujuan untuk mengukur kualitas kevalidan media dan memperoleh masukan atau perbaikan terhadap media pembelajaran yang dikembangkan. Penilaian media juga bertujuan mengetahui kualitas isi dan tujuan, kualitas instruksional serta kualitas teknis media pembelajaran visual basic untuk diterapkan di sekolah. Berikut merupakan data hasil penilaian media dari pakar materi, pakar media, dan guru disajikan dalam Tabel 4.

TABEL 4. Hasil Penilaian Media oleh Pakar Materi dan Pakar Media

\begin{tabular}{lcc}
\hline \multicolumn{1}{c}{ Aspek } & Rata-rata Skor & Kriteria \\
\hline Pakar Materi & 4 & \\
Kualitas Isi dan Tujuan & 4 & Baik \\
Kualitas Instruksional & & Baik \\
Pakar Media & 4 & \\
Kualitas Teknis & 4 & Baik \\
\hline Rata-rata Keseluruhan & & Baik \\
\hline
\end{tabular}

Pada Tabel 4, diperoleh bahwa media yang dikembangkan memiliki isi dan tujuan yang sesuai dengan tujuan pembelajaran. Media juga memberikan petunjuk atau arahan yang benar terhadap capaian belajar. Media yang dikembangkan memiliki tampilan yang menarik dari segi teks, gambar, maupun video.

Berikut merupakan data hasil penilaian media oleh guru matematika disajikan dalam Tabel 5.

TABEL 5. Hasil Penilaian Media oleh Guru Matematika

\begin{tabular}{lcc}
\hline \multicolumn{1}{c}{ Aspek } & Rata-rata Skor & Kriteria \\
\hline Kualitas Isi dan Tujuan & 4,53 & Sangat Baik \\
Kualitas Instruksional & 4,11 & Baik \\
Kualitas Teknis & 4,14 & Baik \\
\hline Rata-rata Keseluruhan & 4,26 & Sangat Baik \\
\hline
\end{tabular}

Pada Tabel 4 dan Tabel 5, diperoleh bahwa media pembelajaran memenuhi kategori sangat baik. Hal ini menunjukkan bahwa media pembelajaran yang dikembangkan dinyatakan valid dan dapat diuji cobakan di lapangan.

Terdapat beberapa perbaikan yang dilakukan sesuai saran dari pakar maupun guru matematika. Diantaranya masih terdapat kalimat-kalimat yang tidak ada kaitannya dengan materi yang ditampilkan dan uraian terlalu panjang, tidak disajikannya tampilan penutup media. Selain itu, disarankan untuk menyajikan tampilan yang menarik perhatian siswa di awal pembelajaran agar siswa bereksplorasi terlebih dahulu.

\section{Implementasi}

Pada tahap implementasi, dilaksanakan uji coba terhadap media pembelajaran yang telah dikembangkan dan layak digunakan. Tahap ini meliputi uji coba media pembelajaran dan pengisian lembar observasi keterlaksanaan pembelajaran.

\section{Uji Coba Media Pembelajaran}

Uji coba produk dilakukan terhadap siswa kelas VIII SMP yang berjumlah 6 orang siswa dengan satu unit laptop digunakan oleh 2 orang siswa. Uji coba dilaksanakan selama empat kali pertemuan dan satu kali tes hasil belajar siswa untuk mengukur keefektifan dari media pembelajaran matematika yang dikembangkan. 


\section{Pengamatan Keterlaksanaan Pembelajaran oleh Observer}

Pada setiap uji coba yang dilakukan, observer yang akan mencatat dan mengamati semua situasi yang terjadi ketika pembelajaran berlangsung. Pengamatan melalui lembar observasi keterlaksanaan pembelajaran berperan penting untuk mengukur kepraktisan terhadap kemudahan penggunaan media oleh guru dan siswa selama proses pembelajaran.

\section{Evaluasi}

Evaluasi dilakukan di setiap tahapan pengembangan. Evaluasi tersebut berupa masukan dan revisi dalam setiap tahap pengembangan. Evaluasi kualitas produk dilakukan oleh pakar materi dan pakar media pada tahap development (pengembangan), serta guru pada tahap implementation (implementasi).

Selain itu, dilakukan evaluasi apakah penggunaan media pembelajaran praktis atau tidak dengan dilaksanakannya pengamatan oleh observer dan pengisian angket respons siswa maupun guru terhadap media pembelajaran. Dilakukan pula evaluasi apakah penggunaan media pembelajaran efektif atau tidak dengan dilaksanakannya tes hasil belajar. Data hasil analisis lembar observasi pembelajaran disajikan pada Tabel 6 .

TABEL 6. Rincian Kegiatan Pembelajaran dengan Media Visual Basic

\begin{tabular}{lcc}
\hline \multicolumn{1}{c}{ Pertemuan } & Persentase & Kriteria \\
\hline Pertemuan Pertama & $85,7 \%$ & Baik \\
Pertemuan Kedua & $100 \%$ & Sangat Baik \\
Pertemuan Ketiga & $100 \%$ & Sangat Baik \\
Pertemuan Keempat & $100 \%$ & Sangat Baik \\
\hline Rata-rata Keseluruhan & $96,43 \%$ & Sangat Kuat \\
\hline
\end{tabular}

Dari Tabel 6 menunjukkan bahwa uji coba media berlangsung dengan lancar pada pertemuan kedua, ketiga, dan keempat. Sedangkan pada pertemuan pertama, siswa mengalami kesulitan ketika ingin menemukan dan menjalankan video pembelajaran.

\section{Pengisian Angket Respons Guru dan Siswa terhadap Media}

Berikut merupakan hasil analisis angket respons guru terhadap media pembelajaran visual basic disajikan pada Tabel 7 .

TABEL 7. Hasil Analisis Angket Respons Guru terhadap Media

\begin{tabular}{lccc}
\hline Aspek & & $\begin{array}{c}\text { Rata-rata } \\
\text { Skor }\end{array}$ & Kriteria \\
\hline Kualitas Isi dan Tujuan & Ketepatan & 5 & Sangat Baik \\
& Kepuasan & 5 & Sangat Baik \\
Kualitas Instruksional & Keingintahuan & 4 & Baik \\
& Semangat & 4 & Baik \\
Kualitas Teknis & Kemudahan & 4,5 & Sangat Baik \\
& Ketertarikan & 4 & Baik \\
\hline Rata-rata Keseluruhan & & 4,42 & Sangat Baik \\
\hline
\end{tabular}

Pada Tabel 7 menunjukkan bahwa media pembelajaran yang dikembangkan menyampaikan materi bangun ruang dengan tepat dan dapat menarik perhatian siswa sehingga proses pembelajaran menjadi tidak membosankan.

Pada Tabel 8 menunjukkan bahwa selama proses pembelajaran menggunakan media, siswa merasa senang dan menjadi aktif saat belajar dengan menggunakan bantuan media visual basic. 
Hal ini menunjukkan bahwa kualitas media yang dikembangkan ditinjau dari kepraktisan memenuhi kualifikasi praktis berdasarkan keterlaksanaan pembelajaran, respons guru dan respons siswa terhadap media.

Berikut merupakan hasil analisis angket respons siswa terhadap media pembelajaran visual basic disajikan pada Tabel 8.

TABEL 8. Hasil Analisis Angket Respons Siswa terhadap Media

\begin{tabular}{llcl}
\hline Aspek & & $\begin{array}{c}\text { Rata-rata } \\
\text { Skor }\end{array}$ & Kriteria \\
\hline Kualitas Isi dan Tujuan & Rasa Senang & 4,92 & Sangat Baik \\
& Minat & 4,75 & Sangat Baik \\
Kualitas Instruksional & Keaktifan & 4,84 & Sangat Baik \\
& Keseriusan & 4,83 & Sangat Baik \\
Kualitas Teknis & Kemudahan & 4,67 & Sangat Baik \\
& Ketertarikan & 4,83 & Sangat Baik \\
\hline Rata-rata Keseluruhan & & 4,8 & Sangat Baik \\
\hline
\end{tabular}

Berikut merupakan hasil analisis tes hasil belajar siswa disajikan pada Tabel 9.

TABEL 9. Deskripsi Tes Hasil Belajar Siswa

\begin{tabular}{cc}
\hline Deskripsi & Kelompok Uji Coba \\
\hline Jumlah Subjek & 6 \\
Rata-rata nilai & 80,67 \\
Jumlah siswa yang tuntas & 5 \\
Jumlah siswa yang tidak tuntas & 1 \\
Persentase ketuntasan & $83,3 \%$ \\
Nilai maksimum & 90 \\
Nilai minimum & 74 \\
\hline
\end{tabular}

Kriteria ketuntasan minimal mata pelajaran matematika di SMP adalah 75. Siswa dikatakan tuntas apabila mendapatkan nilai $\geq 75$. Pada Tabel 9 menunjukkan bahwa terdapat 5 siswa yang tuntas dan hanya 1 orang siswa yang tidak tuntas serta diperoleh persentase ketuntasan klasikal sebesar 83,3\% dengan kriteria sangat baik. Sehingga media pembelajaran visual basic yang dikembangkan dinyatakan efektif dan dapat digunakan dalam proses pembelajaran matematika khususnya pada materi bangun ruang sisi datar.

\section{KESIMPULAN}

Media pembelajaran matematika berbasis visual basic memenuhi kualifikasi valid berdasarkan kriteria penilaian media oleh pakar materi dan media diperoleh skor rata-rata 4 dari skor maksimal 5 dengan kriteria baik. Penilaian media oleh guru diperoleh skor rata-rata 4,26 dengan kriteria sangat baik.

Kualitas media yang dikembangkan ditinjau dari kepraktisan memenuhi kualifikasi praktis berupa kemudahan penggunaan. Data hasil angket respons guru diperoleh skor rata-rata 4,42 dengan kriteria sangat baik. Data hasil angket respons siswa diperoleh skor rata-rata 4,8 dengan kriteria sangat baik. Lembar observasi keterlaksanaan pembelajaran terhadap penggunaan media diperoleh persentase sebesar 96,43\% dengan kriteria sangat baik. Dengan demikian media dinyatakan praktis.

Kualitas media dikatakan efektif jika para pakar dan pengguna menyatakan bahwa media tersebut efektif dan memberikan hasil yang sesuai dengan harapan. Keefektifan media dapat 
diukur dengan dilakukannya tes hasil belajar siswa. Persentase ketuntasan klasikal sebesar $83,3 \%$ dengan kriteria sangat baik, sehingga media dinyatakan efektif.

Pengembangan media pembelajaran yang dilakukan telah memenuhi kualifikasi valid, praktis, dan efektif. Hal ini menunjukkan bahwa media pembelajaran matematika berbasis visual basic layak untuk digunakan sebagai sumber belajar di dalam proses pembelajaran. Pada penelitian ini, pengembangan media masih terbatas pada pokok bahasan bangun ruang sisi datar terkhusus kubus dan balok sehingga perlu dilakukan pengembangan media pada materi yang lain.

\section{DAFTAR PUSTAKA}

Abdussakir. (2009). Pembelajaran Geometri Sesuai Teori Van Hiele. Madrasah, 2(1).

Faizah, Rahma, U, \& Dara, Y. P. (2017). Psikologi Pendidikan: Aplikasi Teori di Indonesia. Malang: UB Press.

James \& James. (1976). Mathematics Dictionary. New York: Van Nostrand Rienhold.

Kusrini \& Koniyo, A. (2007). Tuntunan Praktis membangun sistem informasi Akuntansi dengan Visual Basic dan Microsoft SQL Server. Yogyakarta: ANDI.

Kuswanto, J. (2017). Pengembangan Game Berhitung dengan Menggunakan Visual Basic 6.0 pada Mata Pelajaran Matematika Kelas II di SD Negeri 3 OKUT. Jurnal Educative, 2(1). 66-67.

Madja, M. S. (1992). Perancangan dan Implementasi Perangkat Ajar Geometri SMTA (Tesis tidak dipublikasikan). PPS UI, Jakarta.

Muslimin \& Sunardi. (2019). Analisis Kemampuan Penalaran Matematika Siswa SMA pada Materi Geometri Ruang. Jurnal Kreano, 10(2). 171-172.

Prayoga, D, A. (2018). Media Pembelajaran Mengenal Jenis Batuan Berbasis Augmented Reality pada Perangkat Android. Jurnal Informatika Merdeka Pasuruan, 3(3).

Rohaeti, E. E, Bernard, M, \& Novtiar, C. (2019). Pengembangan Media Visual Basic Application untuk Meningkatkan Kemampuan Penalaran Siswa SMP dengan Pendekatan Open-Ended. Supremum Journal of Mathematics Education, 3(2).

Rosmayanti, D dan Zanthy, L. S. (2019). Pengembangan Media Pembelajaran Berbasis Visual Basic Application Powerpoint pada Materi Sistem Persamaan Linear Dua Variabel. Jurnal Pembelajaran Matematika Inovatif, 2(6). 411-412.

Sudarman. (2000). Pengembangan Paket Pembelajaran Berbantuan Komputer Materi Luas Dan Keliling Segitiga untuk Kelas V Sekolah Dasar (Tesis tidak dipublikasikan). PPS UM, Malang.

Sudjana, N. (2013). Penilaian Hasil Proses Belajar Mengajar. Bandung: PT Remaja Rosdakarya.

Suwaji, U. T. (2008). Permasalahan Pembelajaran Geometri Ruang SMP dan Alternatif Pemecahannya. Yogyakarta: Pusat Pengembangan dan Pemberdayaan Pendidik dan Tenaga Kependidikan Matematika.

Widoyoko, E. P. (2009). Evaluasi Program Pembelajaran. Yogyakarta: Pustaka Pelajar. 